
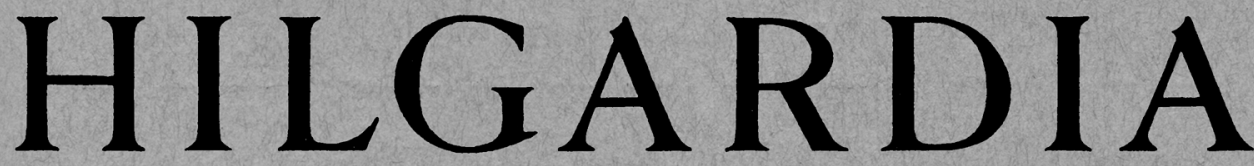

A Journal of Agricultural Science Published by the California Agricultural Experiment Station

CONTENTS

CHARACTERS, DISTRIBUTION, AND FOOD PLANTS OF PHLEPSID LEAFHOPPER VECTORS OF CALIFORNIA ASTER-YELLOWS VIRUS DWIGHT M. DELONG and HENRY H. P. SEVERIN

EVIDENCE OF NONSPECIFIC TRANSMISSION OF CALIFORNIA ASTER-YELLOWS VIRUS BY LEAFHOPPERS

HENRY H. P. SEVERIN

UNIVERSITY OF CALIFORNIA · BERKELEY, CALIFORNIA 


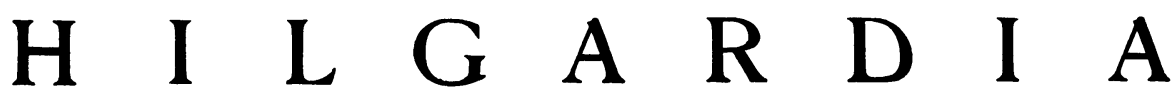 \\ A Journal of Agricultural Science Published by \\ the California Agricultural Experiment Station
}

VoL. 17

OCTOBER, 1945

No 1

\section{CHARACTERS, DISTRIBUTION, AND FOOD PLANTS OF PHLEPSID LEAFHOPPER VECTORS OF CALIFORNIA ASTER-YELLOWS VIRUS ${ }^{1}$}

\author{
DWIGHT M. DELONG ${ }^{2}$ AND HENRY H. P. SEVERIN ${ }^{3}$
}

\section{INTRODUCTION}

SEVERIN $(1934,1940)^{4}$ has previously reported that 3 species and 1 physiological race of leafhoppers transmit the California aster-yellows virus. The present paper deals with the characters, distribution, habitat, and food plants of six species of phlepsid leafhopper vectors. A companion paper (Severin, 1945) presents evidence that the transmission of the virus by the 6 species is not specific.

The genus Phlepsius was established by Fieber (1866) for a small number of European species. Van Duzee (1892) published the first paper on North American forms and recorded 18 species, including 13 new ones. Later his catalogue (Van Duzee, 1917) recorded 63 species and 1 variety of Phlepsius, including 7 species occurring in California. Ball (1918), who recorded the Mexican and Central American species, established 4 new subgenera. Osborn and Lathrop (1923), publishing a synopsis of the genus, discussed 89 North American species and 1 variety of both genera, and recorded 11 species occurring in California. After their paper had appeared, DeLong (1923) discussed the food plants and habitats of some of the North American Phlepsius. Ball (1927) discussed the synonomy of North American phlepsids and established 1 new subgenus. A later paper (Ball, 1931) described some new species and varieties of Phlepsius. DeLong and Caldwell (1937) in their check list of the Cicadellidae of America, north of Mexico, recorded 69 species and 4 varieties in the genus Phlepsius, 5 species occurring in California ; and 29 species and 1 variety in the genus Texananus, 7 species distributed in California.

DeLong (1938a) described 4 new species of Texananus and 3 new species of Phlepsius. In the same year (1938b), he described 3 new species of Texananus, one of which, pergradus, is a vector discussed in this paper.

DeLong also (1938c) studied the male genitalia as distinguishing characters of closely related species, or of species regarded as synonymous with the genus

\footnotetext{
${ }^{1}$ Received for publication November 8, 1944.

${ }^{2}$ Professor of Entomology, Ohio State University, Columbus, Ohio.

${ }^{3}$ Entomologist in the Experiment Station.

"See "Literature Cited" for complete citation, referred to in the text by author and date of publication.
} 
Phlepsius of North America. The ventral segment of the female was illustrated as an aid to be used in identification if the males were not included in the series. Keys were constructed for the species in 3 subgenera, including 46 species and 1 variety of Phlepsius, 9 species and 1 variety of Pendara, 6 species of Paraphlepsius, 1 species of the new subgenus Josanus, and 1 species of Zioninus, or a total of 63 species and 2 varieties all belonging to the typical Phelpsius group.

DeLong (1939) discussed the members of the majestus group of Texananus and described 4 new species. In the following year (1940) he discussed the species of these 2 genera occurring in Mexico, illustrating the genitalia of all the Mexican species and describing 9 new species. Later (1943) he described 3 more new species of western Texananus, 1 of which, latipex, is also a vector of the aster-yellows virus. Then, again, in two separate papers (1944 $a$ and 1944b) DeLong described 13 more new species of the Mexican fauna of Phlepsius and Texananus, listing all the species of these 2 genera occurring in Mexico and illustrating the male and female genital structures.

Until 1918, all the leafhoppers with brown ramose pigment lines were placed in Phlepsius; the whole group commonly was called the phlepsids. That year, Ball separated the narrow-headed forms, which he named Texananus. Because the European-type species is narrow headed, the name Texananus is likely to become a synonym of Phlepsius, whereas the broad-headed group will probably become Paraphlepsius.

\section{GENERAL DISTRIBUTION}

The species of Phlepsius and Texananus reach their greatest known abundance in the temperate regions of North America. Probably the greatest number of species would be found in the lower or central Mississippi Valley. Examining the genus Phlepsius proper, one finds that approximately half of the known North American species occur in the southeastern states, whereas about one fourth are northeastern in distribution. When compared with this eastern predominance of species, about 7 per cent occur in the southwestern states, 7 per cent in the plains states, and 13 per cent in the western United States and western Canada.

If the species of Texananus are considered in like manner, the predominance is reversed, for these are most abundant in the western and southwestern states. More than 35 per cent of the group are southwestern in distribution, and slightly less than that number are western and northwestern. Only 5 per cent are southeastern, approximately the same number are plains species, and some 15 per cent are northeastern in distribution. Apparently, then, the genus Phlepsius, comprising about twice as many species as Texananus, is predominantly eastern; Texananus is predominantly western. This supposition is borne out by recent work upon the Mexican fauna of this group : the species of Texananus are fairly abundant in Mexico; those of Phlepsius are rather scarce. Were it not for the fact that the subgenus Tropicanus, together with several recently described species, is definitely tropical, the genus Texananus would be decidedly predominate in distribution.

Even if the species of Tropicanus are included, the genus Phlepsius is still represented in Mexico by less than one fourth the number occurring in the 
United States, whereas two thirds as many species of Texananus have been recorded for Mexico as for this country.

In connection with the western distribution of these two groups, one notes that 5 of the 6 vectors of the aster-yellows virus in California belong to the genus Texananus.

\section{HABITAT AND FOOD PLANTS}

The habitat may range from bog or marsh to the arid southwestern plains. Most of the species feed upon grass or herbaceous plants and are found under varying conditions. Some occur on the herbaceous growth of the pine woodland floor, and several are abundant in swamp and marsh. Certain of these species are common in the Florida everglades, either on the maiden canesawgrass association or in the moist prairies. In the northern fresh-water marsh, several species occur on the Carex-Phragmites association or the Juncus-Eleocharis-Scleria association. Still others are found in a prairiegrass habitat. A few species occur in the sphagnum-tamarack bog association, whereas others are manzanita species, confined to Arctostaphylos and similar types of vegetation.

Though few species live upon trees, one interesting group is the brown-andwhite-banded species, all of which feed upon pine. Certain species live upon the southern pines, Pinus palustris, $P$. caribaea, and the like; others live upon the northern white pine, $P$. Strobus; and still other northern species on $P$. rigida and $P$. virginiana. Certain phlepsid species, distinct from those in the United States, are found harbored by the Mexican species of pine.

The meadow, upland pasture, and other grazing areas support large populations of several species. Phlepsius irroratus (Say) is both the most common and the most widely distributed species of the genus. The character of the meadow may vary to a high degree. The grassy area may be high or rolling and well drained, or it may be a low, wet meadow ; in consequence, the kind of plant and the humidity factor may vary decidedly. Such conditions determine largely the occurrence and abundance of different species in the various areas of the United States. Thus each of the species of Poa, Andropogon, Aristida, Bouteloua, and other grasses has its specific kinds of phlepsids.

The optimum habitat for several species is found in open woodland areas of the deciduous forest, especially in the mixed mesophytic forest, where the humidity and ground moisture are rather high and there is a rich growth of herbaceous plants. Some species live in more restricted parts of these forests, such as the ground layer of a mixed hemlock-beech woodland. The Texananus majestus group occurs only in the more densely shaded woodlands, on the herbaceous ground layer.

\section{IDENTIFICATION AND SEPARATION OF SPECIES}

The narrow-headed species, being similar in color and external appearance, cannot be easily distinguished by these characters. The last ventral segment of the female abdomen and the chitinous structures of the genital chamber, particularly the aedeagus, are the most dependable means of separating the species of this group. Illustrations of these genital structures are appended as an aid in identifying or separating these species of Phlepsius and Texananus. 


\section{KeY TO THE Six SPECIES}

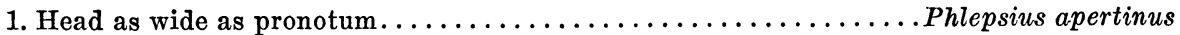

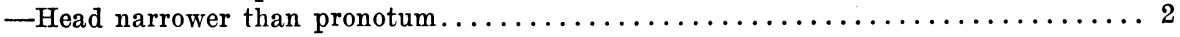

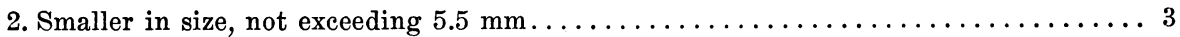

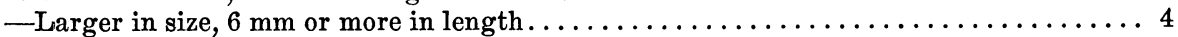

3. Female segment with a rather broad, rectangular median notch. Male styles tapered, narrow on apical third, the sickle-shaped portion of aedeagus narrow, with a long, slender, basal "handle" and without a thumb at base of curved portion...........

Texananus lathropi

-Female segment with a short, narrow V-shaped notch at middle of broadly excavated portion. Male styles broad on apical third; the sickle-shaped portion of aedeagus with a short, broad basal "handle" and a long thumb protrusion at base of curved portion extending more than halfway to apex..................Texananus pergradus

4. Female segment slightly produced at middle, forming a blunt tooth on either side of median V-shaped notch. Male plates long, tapered to acutely pointed apices, which reach or exceed apices of pygofer.................... Texananus spatulatus

-Female segment broadly excavated on posterior margin, not produced at middle. Male plates short, rounded at apex or with blunt tips, not reaching apex of pygofer..... 5

5. Female segment broadly excavated, without a median notch. Male plates broadly rounded, together semicircular in shape. Aedeagus ventral process short, thick, with prominent dorsally and ventrally produced processes at blunt apex. The dorsal portion is a small, sickle-shaped process................... Texananus oregonus

-Female segment broadly excavated, with a short, median V-shaped notch. Male plates short, divergent at apex, and bluntly pointed. Aedeagus ventral process slender, simple, elongate. The dorsal portion is sickle-shaped, with apex bifid.Texananus latipex

\section{PHLEPSIUS APERTINUS OSBORN AND LATHROP}

\section{(Plate 1)}

The head of Phlepsius apertinus is a little wider than the pronotum, and the anterior portion of the elytra appears to have a pale band. The length is 6 to $6.5 \mathrm{~mm}$. The vertex is bluntly angled anteriorly and acutely angled, with the front forming a rather definite margin. The length at the middle is less than half the basal width between the eyes. The vertex, pronotum, and scutellum are white, with brown or black irrorations. There is a pale, irregular band in front of the middle of the clavus. There are a few large, whitish areas on the apical portion of the clavus and elytra. The costa is marked with several black spots. The front is black at the base; it is paler, with broken arcs, below.

In the female the last ventral segment slopes on the lateral margins to the rounded posterior angles. The posterior margin is broadly, deeply excavated almost to the base of the segment, the excavation being broadest at the base. The margins of the apex of the excavation are formed by broad, toothlike, pointed projections extending from the posterior margin at either side. The male plates are elongate, broad at the apex, rounded to the outer margins. The styles are long and narrow, extending almost to the apex of the plates, tapered to bluntly pointed apices. The aedeagus is rather short, broadened at the base, and tapered to a pointed apex. In a lateral view it appears barbed, with one barb close to the apex on the posterior margin and another barb more basal on the anterior margin. There is a short process near the base, extending anteriodorsally. The pygofer bears a long, slender spine on the ventro-caudal margin.

Geographic Range.-Phlepsius apertinus is found in Oregon and California. 
Distribution and Food Plants in California.-This species of leafhopper is common in fields of alfalfa (Medicago sativa) in the Santa Clara, San Joaquin, and Sacramento valleys. The localities in which the food plants grow and the populations were collected are as follows:

Sonoma County : A small number of adults were swept from pasture vegetation at Triniti, on June 4, 1943, by N. W. Frazier.

Santa Clara County : In Gilroy, on May 10, 1943, a few adults were captured in an alfalfa field by J. H. Freitag.

Sacramento County: In a locality known as the "Sacramento Pocket," on September 5, 1941, many adults were taken by H. H. P. Severin and N. W. Frazier, by sweeping cocklebur (Xanthium canadense), which grew in the shade of trees. On September 12, 1941, also, Severin found adults in abundant quantity in fields of alfalfa and Ladino clover (Trifolium repens L. var. latum McCarthy), and wild licorice (Glycyrrhiza lepidota).

Merced County: Two females were swept from pasture vegetation by N. W. Frazier on the summit of Pacheco Pass, May 6, 1943.

Madera County : At Madera, on October 9, 1941, a few adults were caught in an alfalfa field by N. W. Frazier.

Fresno County: On October 9, 1941, at Fresno and Selma, a small number of adults were taken in alfalfa fields by N. W. Frazier.

Tulare County: On May 4, 1941, at Woodlake, many adults were collected in an alfalfa field by N. W. Frazier. Later, on June 1 and on July 4, 1944, adults were commonly taken in a grassy Ladino clover field by J. H. Freitag. At Exeter, on October 9, 1943, adults were collected in abundant numbers by N. W. Frazier on bur-clover (Medicago hispida), as well as on annual yellow sweetclover (Melilotus indica), on common foxtail (Hordeum murinum), and on certain grasses.

\section{TEXANANUS LATHROPI BAKER}

\section{(Plate 2)}

Texananus lathropi is one of the short, broad species of the ovatus group. The length is 5.0 to $5.5 \mathrm{~mm}$. The vertex is short and blunt, almost twice as wide between the eyes at the base as the median length; the margin is thick. The vertex, pronotum, scutellum, and inner border of clavus are yellow, with fuscous irrorations. The elytra is whitish and hyaline, marked with dark brown and fuscous. The costal area has darker spots.

The female segment is short and is broadly, shallowly excavated, with a deep quadrangular excavation at the middle.

The male valve is broadly triangular; the plates are strongly convexly rounded to a produced blunt apex on the inner margin. The styles are broad at the base, concavely rounded on the outer margin, and tapered to blunt apices, which are turned outward. The aedeagus is composed of two parts, the lower part being rather long and narrow in lateral view, tapered to a pointed apex, and the dorsal part being sickle-shaped, with a rather long, straight basal portion.

This species was first described as Phlepsius annulatus (Osborn and Lathrop, 1923); but Baker (1925), finding that name preoccupied, named the leafhopper P. lathropi. 
Geographic Range.-One female was reported to have been collected from the base of Mt. Hood, and one male from Alsea Mountain (Oregon) on undergrowth at the edge of a fir forest. The species was taken at Los Angeles, California, by D. W. Coquillett; and in Nevada by C. F. Baker (Baker collection).

Distribution and Food Plants in California.-The localities and food plants of Texananus lathropi in California are as follows :

Sonoma County : At Triniti, on June 25, 1939, a mixed population containing 22 specimens of Texananus lathropi and T. latipex was collected by N. W. Frazier on drying pasture vegetation in a mountainous area at an elevation of 1,800 feet. Later collections in the same locality were made by Frazier as follows : May 29, 1942, when 10 females were captured on bur-clover, wild pea (Lathyrus Bolanderi) and Thermopsis macrophylla; on June 4, 1943, when 1 female was taken on wild pea; and on June 8, 1944, when 1 male was caught on pasture grasses and weeds.

Alpine Valley : On March 28, 1942, N. W. Frazier collected 8 females on bur-clover.

Marin County : At San Rafael, April 5, 1943, 1 female was collected, probably on wild pea, by N. W. Frazier. At Montara, July 31, 1942, 1 female was captured on tree lupine (Lupinus arboreus), by H. H. P. Severin.

Napa County: N. W. Frazier collected 1 female on wild pea at Dry Creek School on April 5, 1943.

Merced County : N. W. Frazier also caught 1 female on pasture vegetation at the entrance to Pacheco Pass on December 19, 1941.

Tulare County: At Exeter, October 10, 1939, 1 male and 3 females were taken on puncture vine (Tribulus Terrestris) by H. H. P. Severin.

This leafhopper occurs in the fog belt and in the interior regions of California. The dates of collection indicate that it overwinters in the adult stage.

\section{TEXANANUS PERGRADUS DELONG}

\section{(Plate 3)}

This is a small species of the ovatus group. The length is 4.5 to $5.5 \mathrm{~mm}$. The vertex is bluntly angled, about $11 / 2$ times as wide between the eyes at the base as the median length. The color is variable. In darker specimens a brown spot occurs on either side of the apex, and a broken brown band between the eyes on the disc. The scutellum has four brown spots on the anterior margin. The elytra is pale, with dark-brown ramose pigment lines. There are three pale, distinct spots along the commissure.

The female last ventral segment is rather strongly, broadly excavated, with a short $\mathrm{V}$-shaped notch at the apex of the excavation.

The male valve is produced and triangular. The plates are short, broad, strongly, convexly rounded, together appearing semicircular. The styles are elongated, narrowed except at the base. The apex is bluntly angled. The aedeagus in lateral view shows a slender, delicate, ventral process and a broader sickle-shaped dorsal process, which has a long prominent thumb at the base of the curved portion.

Geographic Range.-The states in which Texananus pergradus was collected include Oregon, California, Utah, Colorado, Arizona, New Mexico, Texas, and Mexico. 
Distribution and Food Plants in California.--As determined by N. W. Frazier, the localities and food plants of this leafhopper in California are as follows :

San Luis Obispo County: Two males and 1 female were caught in pasture and abandoned vineyards at Santa Maria on June 12, 1942.

Ventura County: On June 11, 1942, at Cavin Station, 3 miles east of Fillmore, 27 males and 24 females were collected on annual yellow sweetclover and annual burweed (Franseria acanthicarpa), growing in the Santa Clara river bottom.

Orange County: On June 5, 1942, at Anaheim, 2 males and 1 female were swept from annual burweed growing in the Santa Ana river bottom.

Riverside County : At Banning, June 5, 1942, 3 males and 12 females were collected on annual burweed.

San Diego County: At Boulevard, 5 males and 5 females were taken on Franseria sp. on June 7, 1942.

San Bernardino County: On June 5, 1942, at the entrance to Cajon Pass, 1 male and 2 females were captured on Lotus sp.

Tulare County: On pasture vegetation along a riverbank at Woodlake on May 4, 1940, 12 males and 14 females were coilected.

San Joaquin County : At Byron, November 12, 1942, 1 male was swept from Bermuda grass.

\section{TEXANANUS SPATULATUS VAN DUZEE \\ (Plate 4)}

This is the largest and most common species of the genus in the southwestern United States and Mexico. The length is 6.5 to $7.0 \mathrm{~mm}$. The vertex is produced and bluntly angled, almost twice as wide between the eyes at the base as the median length. The margin is thick and rounded. The color is brown. The vertex has a mottled transverse band between the eyes, anterior to which are two triangular mottled spots.

The female last ventral segment is short, with broadly rounded lateral angles. The posterior margin is slightly produced at the center and bears a V-shaped notch extending about one fourth the distance to the base. The posterior margin is broadly, shallowly excavated on either side, between the lateral angles and the produced tooth on each side of the median notch.

The male valve is short and triangular. The plates are long, tapered to acutely pointed tips, which extend to the apex of the pygofers. The styles, broad at the base, are rapidly narrowed to slender apical portions, which are pointed on the outer apical margins. The aedeagus has a pair of long, slender ventral processes and a dorsal process that arises at the base, is bent caudad, and forms a ventral and dorsal branch at about half its length. The ventral branch is long, slender, and acutely pointed.

Geographic Range.-The distribution of this species includes California, Colorado, Kansas, Texas, and Mexico.

Distribution and Food Plants in California.-The localities and food plants of this leafhopper in the San Joaquin Valley were as follows:

Merced County: At the summit of Pacheco Pass, May 6, 1942, 136 adults were collected on pasture vegetation by N. W. Frazier. 
Tulare County: On October 10, 1941, at Ivanhoe, 4 males and 8 females were collected on rough pigweed (Amaranthus retroflexus), by H. H. P. Severin, N. W. Frazier, and J. H. Freitag. At Exeter, on October 10, 1941, 1 male was captured on puncture vine, by H. H. P. Severin; on April 1, 1942, 5 males and 5 females were taken on redstem filaree (Erodium cicutarium), by N. W. Frazier ; and at Woodlake, on January 8, 1942, he collected 3 males, 3 females, and 28 nymphs from redstem filaree, and from whitestem filaree, (E. moschatum).

Kern County: At Delano, October 10, 1941, 2 males and 1 female were caught in an alfalfa field by H. H. P. Severin. On December 21, 1941, at Arvin, 62 males and 68 females were taken below leaves of nettle-leaf goosefoot (Chenopodium murale), and also on grass under leaves in grape vineyards, by N. W. Frazier and J. H. Freitag.

Evidently this leafhopper overwinters in the nymphal and adult stages and undergoes an incomplete hibernation.

\section{TEXANANUS OREGONUS BALL}

\section{(Plate 5)}

Texananus oregonus is a rather robust species, $6.5 \mathrm{~mm}$. in length. The vertex, produced and bluntly angled, is about two thirds as wide between the eyes as the median length. It is pale brown, with black markings at the ends of the claval veins along the posterior margin of the elytra. Although it resembles superbus and other species of the genus, the genital structures will easily distinguish it from allied species.

The female last ventral segment is short and broad. The lateral margins slope to rounded posterior angles. The posterior margin is broadly, shallowly excavated, and brown-margined.

The male valve is short and triangular, with a blunt apex. The plates are short, broadly rounded from base to apex. Together they appear semicircular. The pygofers are a little longer than the plates. The styles are broad on the basal two thirds; the apical third is abruptly narrowed and produced as a narrow portion on its inner margin. The aedeagus is bifid at the apex, with a dorsal process arising near the base, which is sickle-shaped on the apical portion. The aedeagus proper is rather short, in lateral view broadened at the apex, with a dorsally directed and a ventrally directed pointed process. The apex is truncate.

Geographic Range.-This leafhopper has been recorded from Washington, Oregon, California, and Mexico.

Distribution and Food Plants in California.-As determined by N. W. Frazier, the localities and food plants of populations collected in California, are as follows :

Sonoma County : At Triniti, on May 12, 1940, 10 males and 12 females were taken on bur-clover and wild pea. On March 28, 1942, 1 male and 5 females were taken on wild pea. On February 13, 1943, 2 males and 1 nymph (a female after the last molt) were captured on an annual species of Lotus and on wild honeysuckle (Lonicera hispidula Dougl. var. californica Jepson). On April 7, 1943, 1 female was swept from wild pea. On June 8, 1944, 2 nymphs (1 male 
and 1 female after the last molt) were caught on pasture grasses and weeds. At Alpine Valley, on March 28, 1942, 4 females were collected on bur-clover. Napa County: Two females were taken on wild pea at Dry Creek School, February 13, 1943.

The collection data show that the adults winter over.

\section{TEXANANUS LATIPEX DEIJONG}

\section{(Plate 6)}

This is one of the short, broad phlepsids of the ovatus group. The length is $6 \mathrm{~mm}$. The vertex is bluntly angled, almost twice as wide between the eyes at the base as the median length. The vertex, pronotum, and scutellum are yellowish, marked with brown ramose pigment. The basal angles of the scutellum have dark-brown spots. The elytra are more heavily marked with brown pigment, with three distinct commissural spots.

The female last ventral segment is short, with rather prominent lateral angles, between which the posterior margin is rather deeply, broadly excavated, with a slight median $V$-shaped notch.

The male valve is triangular. The plates are short, convexly rounded to bluntly pointed, produced, diverging apices. The styles are elongated, concavely curved, and tapered to narrow blunt apices. The aedeagus is composed of an upper and a lower portion. In lateral view the ventral portion is rather long, narrow, and tapered to an acute tip. The dorsal portion is broad, strongly curved, sickle-shaped, broadened apically, and bifid at the apex, forming two stout teeth.

Geographic Range.-Texananus latipex occurs in British Columbia, Washington, Montana, North Dakota, Oregon, Idaho, Wyoming, California, Nevada, Utah, Colorado, Arizona, New Mexico, Texas, and Mexico.

Distribution and Food Plants in California.-The localities in which this leafhopper was collected in California and its food plants are as follows:

Sonoma County: At Triniti, on June 25, 1939, a mixed population of Texananus latipex and T. lathropi was collected on drying pasture vegetation in a mountainous area at an elevation of 1,800 feet. One female was taken on pasture vegetation July 14, 1943, in the same locality. At Alpine Valley, March 28, 1942, 1 female was captured on bur-clover by N. W. Frazier.

San Mateo County: On September 19, 1941, at Half Moon Bay, 1 female and 1 nymph (a female, after the last molt) were taken on spiny clotbur (Xanthium spinosum) by H. H. P. Severin.

Santa Clara County : At Milpitas, February 19, 1943, 3 females were caught in a depleted, grassy alfalfa field by J. H. Freitag. He also collected 1 female in an alfalfa field at San Jose on March 4, 1942 ; and 1 female on grasses in a bog at Gilroy on August 11, 1942.

Alameda County : At Pleasanton, June 30, 1943, 1 female was captured in an alfalfa field by J. H. Freitag.

Madera County: On October 9, 1941, at Madera, 1 female was taken in an alfalfa field by H. H. P. Severin. At Chowchilla, December 19, 1941, 4 females and 2 males were collected on pasture vegetation by N. W. Frazier.

Fresno County: At Fresno, November 17, 1941, 4 females and 2 males were 
caught on redstem filaree, and 2 females were collected on Bermuda grass (Cynodon Dactylon), on April 22, 1942. At Raisin City, on December 22, 1941, 1 female was taken on grass by N. W. Frazier.

Tulare County : At Exeter, on October 9, 1941, H. H. P. Severin captured 1 female in an alfalfa field and 2 females on puncture vine. At Visalia, June 18, 1942, 1 female was caught on inland saltgrass (Distichlis stricta), and at Ivanhoe-Elderwood, April 29, 1943 was collected 1 female on pasture vegetation by N. W. Frazier.

Kern County : On October 10, 1941, at Delano, 1 female was collected in an alfalfa field by H. H. P. Severin.

Evidently Texananus latipex occurs in the fog belt, in the San Joaquin Valley, and in the mountains of Sonoma County. This insect overwinters in the adult stage. 
BAKER, C. F.

\section{LI'TERA'TURE CI'TED}

1925. Nomenelatorial notes on the Jassoidea. Philippine Jour. Sci. 27:159-60.

BALL, E. D.

1918. The phlepsids of Mexico and Central America. Ent. Soc. Amer. Ann. 11:381-92.

1927. Notes on the phlepsids of the subgenus Phlepsius. (Rhynchota Homoptera.) Canad. Ent. 59:262-65.

1931. New species of Phlepsius with notes on others. Pan-Pacific Ent. 8:85-89.

DFLong, D. M.

1923. Food plants and habitat notes on some North American species of Phlepsius. Ohio Jour. Sci. 26:69-72.

1938a. The genus Phlepsius. A study of North American species with special reference to the characters of the male genitalia. Lloydia 1:232-52.

1938b. New species of Texananus and Phlepsius from the United States. Ohio Jour. Sci. $38: 41-44$.

1938c. Three new species of Texananus. Pan-Pacifie Ent. 14:185-86.

1939. The Texananus (Homoptera, Cicadellidae) species of the majestus group, with the description of four new species. Ohio Jour. Sci. 39:235-38.

1940. Los Phlepsidos (Phlepsius y Texananus) de Mexico. Anales de la Escuela Nacional de Ciencias Biologicas 1:379-405.

1943. Three new species of Texananus from the western and southwestern United States. Brooklyn Ent. Soc. Bul. 38:124-28.

1944a. The Mexican species of Phlepsius (Homoptera: Cicadellidae). Wash. Ent. Soc. Proc. 46:85-94.

1944b. The Mexican species of leafhoppers of the genus Texananus (Homoptera: Cicadellidae). Wash. Acad. Sci. Jour. 34:228-39.

DeLong, D. M., and J. S. CALDWELl.

1937. Check list of the Cicadellidae (Homoptera) of America north of Mexico. Ohio State University. $93 \mathrm{p}$.

Fieber, F. H.

1866. Neue Geuttungen und Arten in Homoptera. Zool.-Bot. Gesell. Wien, Verhandl. 6:503-04.

OSBORN, H., and F. H. LATHROP.

1923. The genus Phlepsius in North America (Homoptera). Ent. Soc. Amer. Ann. 16: 310-62.

Severin, H. H. P.

1934. Transmission of California aster and celery-yellows virus by three species of leafhoppers. Hilgardia 8(10):339-62.

1940. Potato naturally infected with California aster yellows. Phytopathology 30(12): 1049-51.

1945. Evidence of nonspecific transmission of California aster-yellows virus by leafhoppers. Hilgardia $17(1): 22-60$.

VAN DUZeE, E. P.

1892. A revision of the North American species of Phlepsius. Amer. Ent. Soc. Trans. $19: 63-82$.

1917. Catalogue of the Hemiptera of America north of Mexico, excepting the Aphididae, Coccidae, and Aleurodidae. Univ. California Pubs. Ent. 2:1-902. 



\section{PLATES}




\section{PLATES}

1. Phlepsius apertinus Osborn and Lathrop

2. Texananus lathropi Baker

3. Texananus pergradus DeLong

4. Texananus spatulatus Van Duzee

5. Texananus oregonus Ball

6. T'exananus latipex DeLong

\section{KEY TO FIGURES ON PLATES}

A-Dorsal view of head, pronotum, and scutellum $B$-Ventral view of male genitalia

(:-Lateral view of male genitalia

1)-Ventral view of female last ventral segment

KEY 'TO FIGURE DETAIL OU'TLINES

- - - - - - style

. - . - . aedeagus

........ dorsal spine of pygofer 


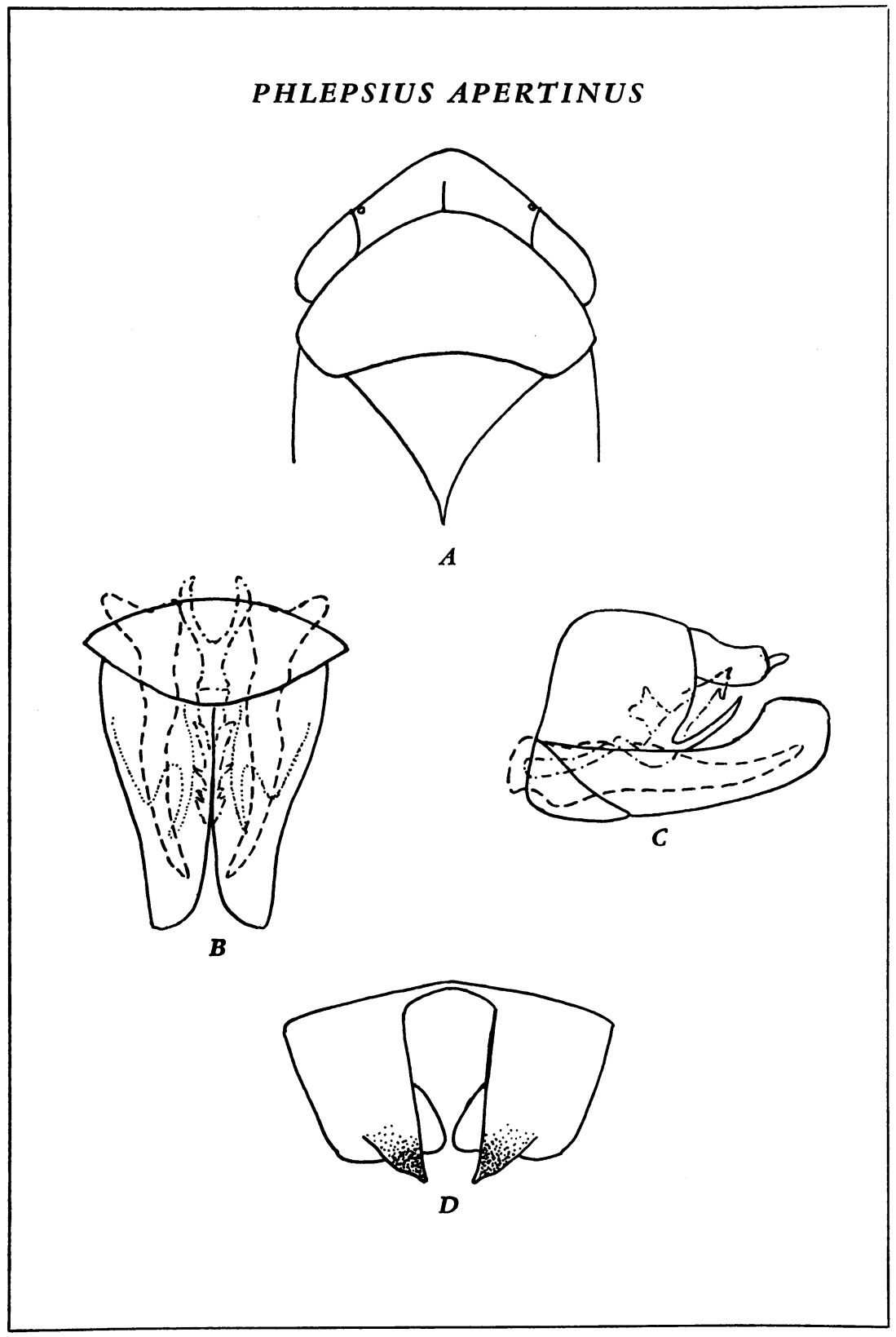

(For explanation of plate see page 14.) 


\section{TEXANANUS LATHROPI}
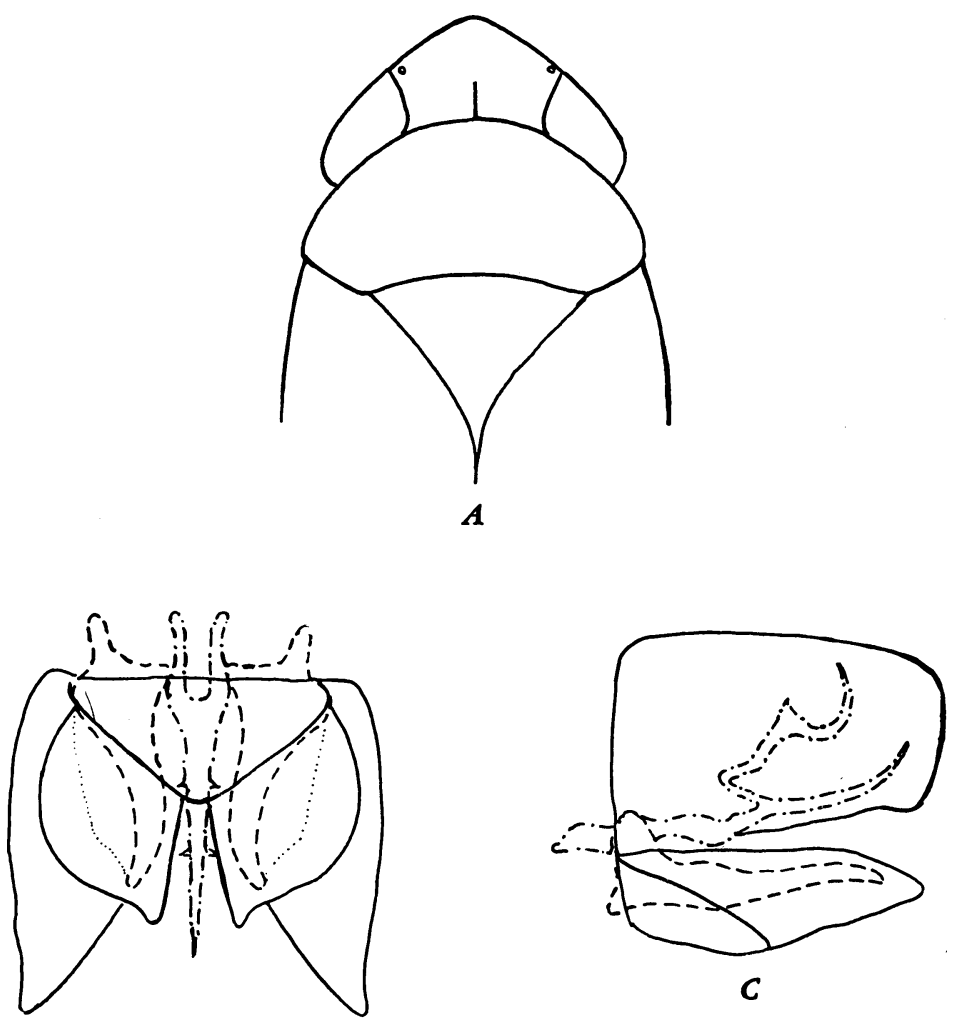

$\boldsymbol{B}$

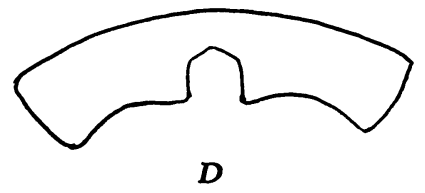

(For explanation of plate see page 14.) 


\section{TEXANANUS PERGRADUS}
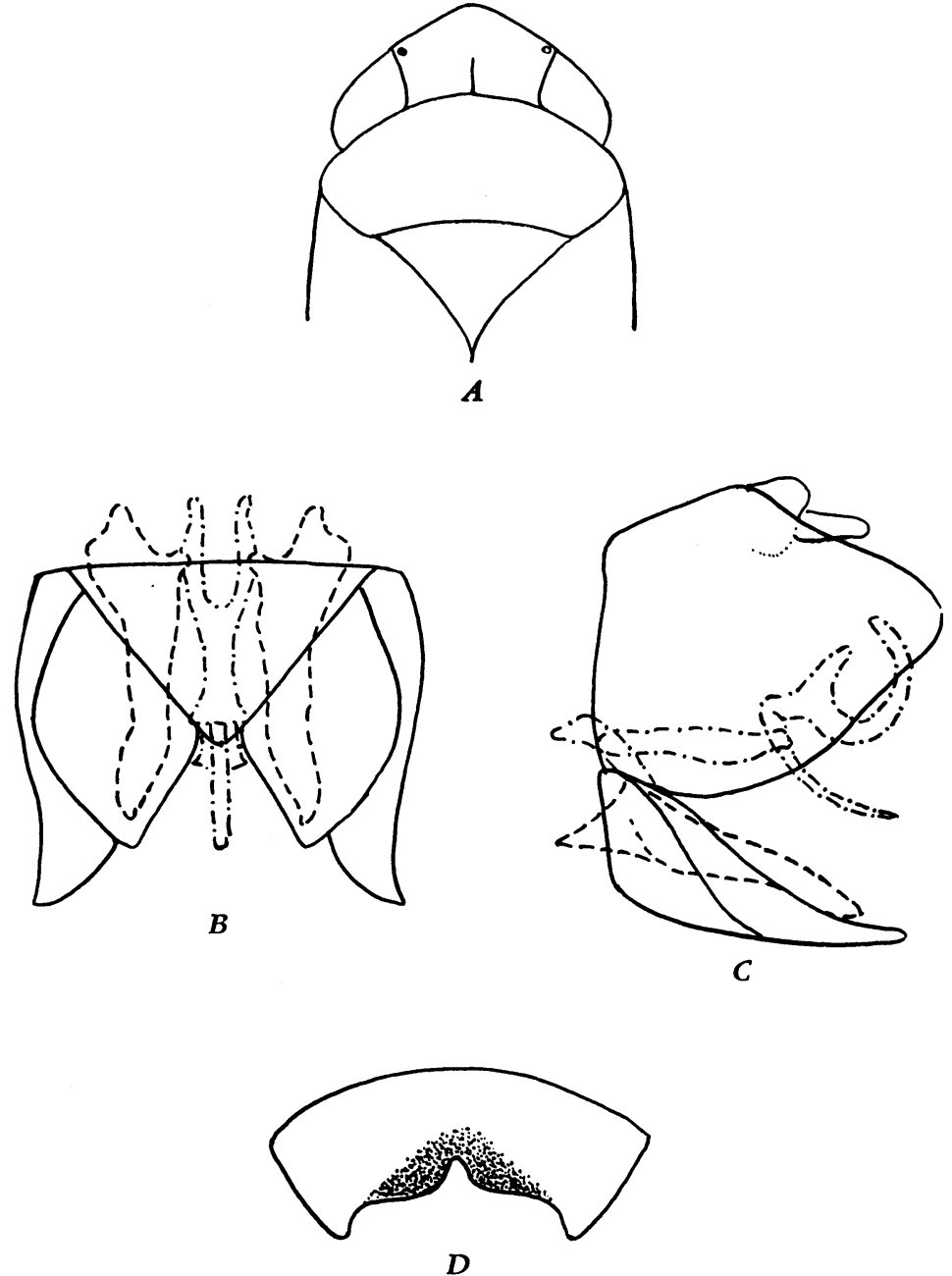

(For explanation of plate see page 14.) 


\section{TEXANANUS SPATULATUS}
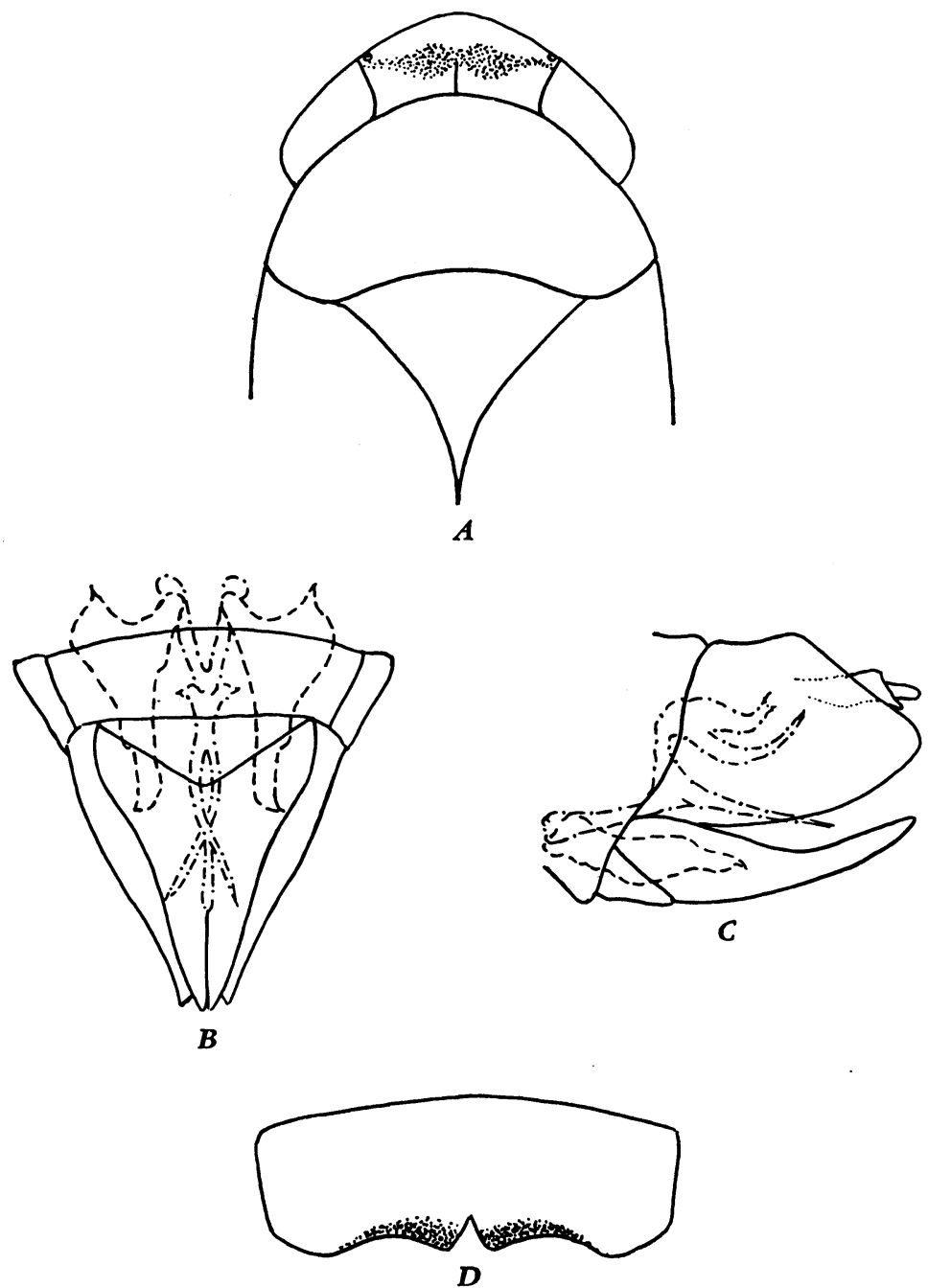

(For explanation of plate see page 14.) 


\section{TEXANANUS OREGONUS}
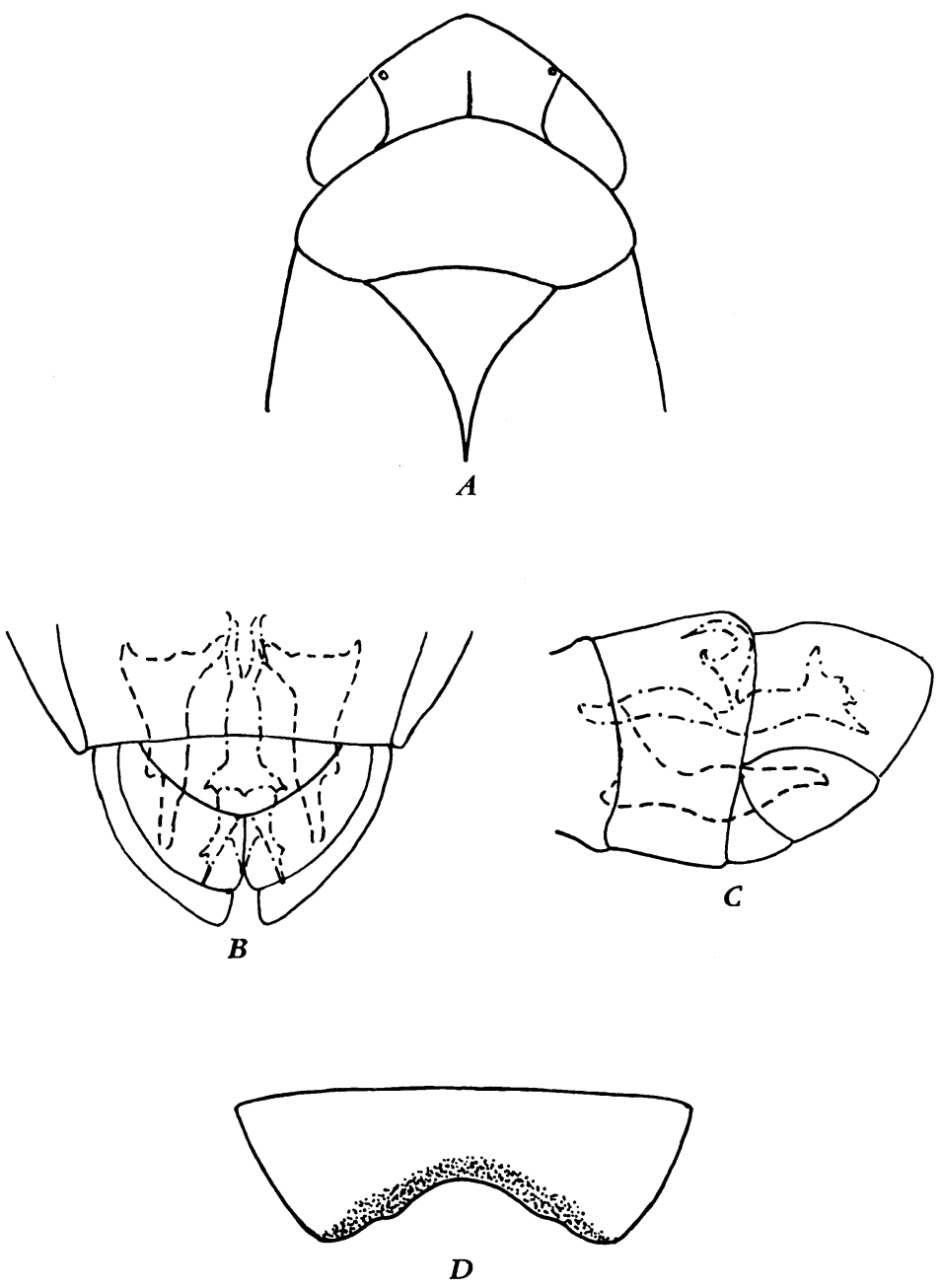

(For explanation of plate see page 14.) 


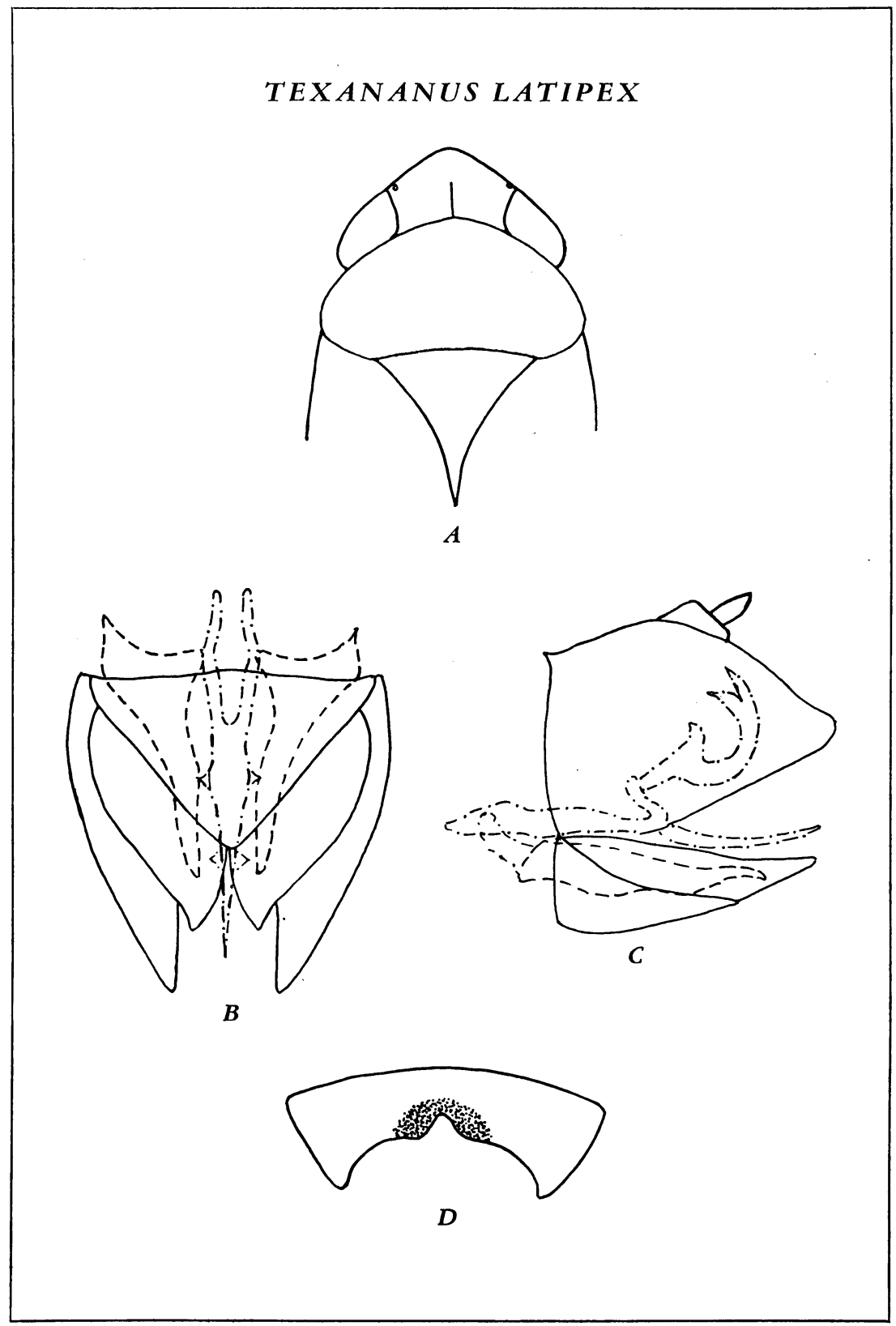

(For explanation of plate see page 14.) 